\title{
Digital competence of higher education professor according to DigCompEdu. Statistical research methods with ANOVA between fields of knowledge in different age ranges
}

\author{
Julio Cabero-Almenara ${ }^{1}$ (D) - Francisco D. Guillén-Gámez ${ }^{2}$ (D) \\ Julio Ruiz-Palmero ${ }^{3}$ (D) Antonio Palacios-Rodríguez ${ }^{1}$
}

Received: 16 December 2020 / Accepted: 16 February 2021/ Published online: 18 March 2021

(C) Springer Science+Business Media, LLC, part of Springer Nature 2021

\begin{abstract}
The tasks of the university educators must be linked to the digital demands posed by the more sophisticated professions of the twenty-first century. Faced with this panorama, the objective of this study is to examine and compare the degree of digital competence of Higher Education educators from different fields of knowledge and different age ranges according to the DigCompEdu framework. A non-probabilistic ex post facto sampling was utilized with 2180 university professors from Andalusia (Spain). The main results of the study provide evidence of an intermediate level of digital competence, for men and women. More specifically, the male professors in Architecture and Judicial \& Social Sciences, younger and older than 40, possessed a higher level, as compared to the other fields. For the female professors, the highest level was found once again in Judicial and Social Sciences, in this case for both age ranges, without a clear trend found for the rest of the fields. For each dimension of the DigCompEdu instrument, the level of competence follows the same trend with respect to the overall level. More research is recommended to validate these preliminary results, as well as the development of training lines of action that are specific and adapted to each field of knowledge.
\end{abstract}

Keywords Digital competence · Higher education · Professors · Fields · ANOVA; educational research methods

Antonio Palacios-Rodríguez

aprodriguez@us.es

Extended author information available on the last page of the article 


\section{Introduction}

The digital society where we find ourselves immersed in has changed the manner in which we access information, communicate and learn. In this context, the role played by digital competences is key for developing continuous learning that is in accordance with the new scenarios that are posed to us (Alexander et al. 2019; Olszewski and y Crompton 2020). The university cannot ignore this reality. The students, as well as the professors from each of the fields of knowledge should respond to the challenges that are continuously posed by the digital society. Therefore, it is necessary to improve the development of the professor's competences related with technology (Guri-Rosenblit 2018). The digital competence of educators (DCE) can be defined as the set of knowledge, abilities and/or skills about Information and Communications Technology (ICT) related to the teaching profession, that can help them to resolve professional and/ or pedagogic problems found in the society of knowledge (Cabero-Almenara and Palacios-Rodríguez 2020; European Union Council 2018; Ghomi and Redecker 2019).

Different competence frameworks have been proposed to analyze the specific competences implied by digital competence, based on different studies (Durán Cuartero et al. 2016; Cabero Almenara and Martínez Gimeno 2019; Lázaro-Cantabrana et al. 2019; Rodríguez-García et al. 2019b; Silva et al. 2019; Cabero-Almenara and PalaciosRodríguez 2020), underlining the following as the most important: European Union Framework of Digital Competence of Educators-DigCompEdu Redecker and Punie 2017); The Framework of the "International Society for Technology in Education" (ISTE) for educators (Crompton 2017); the UNESCO framework of ICT Competency Framework for Teachers (Butcher 2019); Common Framework of digital competence of educators from the "National Institute of Education and Training Technology of Educators (INTEF 2017); Digital Teaching Professional Framework from the United Kingdom (Education and Training Foundation 2019); ICT competences for the professional development of educators from the National Ministry of Education of Colombia (Fernanda et al. 2013); ICT Competences and Standards for the Education Profession from the Ministry of Education of Chile (Elliot et al. 2011).

The importance of measuring professors' digital competencies has gained importance in the last few years in the field of education research, resulting in the appearance of different research studies on the subject (Rodríguez-García et al. 2019a). Their study and analysis is important, as educators tend to have a low digital competence (Dzikite et al. 2017; Ojeniyi and Adetimirin 2016). Nevertheless, there are few studies that jointly analyze and compare the DCE in each of the fields of knowledge where the professors are ascribed to, with the aim of establishing specific training actions that are adapted to the professional context within which the professors develop their academic work. Reducing this training deficit will allow the correct use of the technology in teaching-learning scenarios that are suitable to their educational and research profiles (Cabero-Almenara and Barroso 2016; Pozos and Tejada 2018; Mercader 2019, 2020; Pérez-Díaz 2019; Guillén-Gámez and Mayorga-Fernández 2020a; Padilla-Hernández et al. 2020).

An aspect of the specialized literature has been to detect the different variables that could predict, in one way or another, the level of competence of the professors. One of these, which has been shown to have an effect on the level of competences of the professors, is age. Fernández-Cruz and Fernández-Díaz (2016) attest that the older 
professors and those with a greater teaching experience have a profile of ICT training that is lower than those who are younger or with less experience. Along the same line, other authors have concluded in their work that the age of the educator is important for the mastery of the DCE, with the younger ones possessing a greater level of competence and greater pre-disposition for becoming trained in these aspects (GallardoEchenique et al. 2018; Garzón et al. 2020). Significant differences have also been found as a function of age, on the technical management, with the younger professors having a greater level of instrumental competences (Fernádez dela et al. 2016; López et al. 2019).

As for the digital competences according to field of knowledge, some studies have focused on the field of Social Sciences (Andres and Svoboda 2018; Burgos 2019), with some of them concluding that the educators have a medium-high level of knowledge of the technological resources and tools, with a significant relationship found between knowledge and the use of diverse technologies (Mirete 2016; Fernández-Márquez et al. 2017), although contradicting results have also been found (Fernández-Márquez et al., 2018; Amhag et al. 2019). In the field of Health Sciences, Humanante-Ramos et al. (2019) analyzed the digital competence in the Faculty of Health Sciences at the UNACH (Ecuador), finding deficits in the lack of digital training related with the management and generation of information, as well as the dissemination of knowledge, with results similar to those found in the study by Kingsley and Kingsley (2009). Although in their studies, Fernández-Luque et al. (2017) and Fernández Luque (2019) found a special interest of the health professionals for discovering and acquiring the digital competence demanded by the society of the twenty-first century. In the Experimental and Technological field, the professors possess adequate training on ICT and emerging technologies (Eloy et al. 2019), but not from a didactic or pedagogic point of view, only instrumental (Rodriguez and Martinez 2015). Even more so, López-Pena et al. (2017) studied the teaching guidelines for the Bachelor and Master's degrees related to the use of the ICT in Technical Drawing. The results found that none of the teaching guides included pedagogical strategies related to digital innovation. These results highlight that the integration of ICT in the study plans of university degrees is an urgent need, requiring teacher training (Deumal and Guitert 2015).

Regarding gender differences and the level of digital competence, there is no degree of agreement in the scientific literature of recent years, where males tend to have higher scores (Cooper and Weaver 2003; Jackson et al. 2008; Baek et al. 2010; Tena et al. 2016; Cabero Almenara et al. 2017; Guillén-Gámez et al. 2020). Moreover, a recent meta-analysis of 50 different studies on gender and the attitudes towards the use of technology in part confirmed this view, finding a significant size effect in the male gender, although it was small (Cai et al. 2017). But this has also been observed in for the female gender (Krumsvik et al. 2016; Baloğlu and Çevik 2008). In this context, the meta-analysis by Siddiq and Scherer (2019), with a tally of 46 size effects from 23 empirical studies, found that there were differences in the scores between both genders, being higher for the female sex. Having in mind that different directions have been found in the differences between gender and ICT, it is considered that it is not enough to continue comparing them, but to move science a step forward, conducting genderbased research in parallel, with the aim of tending to their technological needs with specific training plans for each of them. 
Likewise, taking into account the previous studies on the digital competence of Higher Education professors, it is observed than none of them were conducted under the European Framework for the Digital Competency of Educators (DigCompEdu). Altogether, studies have not been found that jointly compared and analyzed the digital competence of university professors according to their field of knowledge, and conducting the corresponding statistical analysis specifically in different ages ranges and in each of the genders separately, with the aim of studying in detail, in which fields, in which gender and in which age range, training on the digital competence of educators is needed. Therefore, the objectives of the study are:

1. To discover the digital competence of the Andalusian Higher Education professors.

2. To discover and compare the digital competence of the Andalusian Higher Education professors from the different fields of knowledge, classified in two age ranges (younger than of equal to 40 and older than 40 years old) for each gender. This cut was decided since the authors checked several age ranges and this was the most significant.

\section{Method}

\subsection{Design and participants}

An ex post facto design with surveys was utilized. The study population corresponded to Higher Education professors in Andalusia (Spain), composed by a total to 17,321 lecturers and researchers (MECD, 2019). With an intentional, non-probabilistic sampling, the respond rate was $13.10 \%$ of the total $(n=2262)$. Once the data was collected, a exploratory analysis was conducted for filtering the database. The final sample was composed by 2180 Higher Education professors. The survey was completed anonymously, thereby preserving the confidentiality of the data.

The sample of professors was composed of five fields of knowledge. Table 1 shows the distribution in percentages as a function of gender and the age range occupied by each professor. The ages ranges established were professors younger than 40 years old, and those older than 40 years old.

Table 1 Description of the participants

\begin{tabular}{lllllll}
\hline & \multicolumn{1}{l}{ Women } & & \multicolumn{2}{l}{ Men } & Total \\
\cline { 2 - 3 } \cline { 5 - 6 } & Younger than 40 & 40 or older & & Younger than 40 & 40 or older \\
\hline Arts and Humanities & $16.7 \%(45)$ & $18.5 \%(131)$ & $15.1 \%(44)$ & $13.1 \%(119)$ & 339 \\
Sciences & $18.5 \%(50)$ & $10.9 \%(77)$ & $14.7 \%(43)$ & $17.6 \%(160)$ & 330 \\
Health Sciences & $18.5 \%(50)$ & $16.1 \%(114)$ & $20.9 \%(61)$ & $9.6 \%(87)$ & 312 \\
Engineering and Architecture & $9.6 \%(26)$ & $10.7 \%(76)$ & $20.9 \%(61)$ & $28.7 \%(261)$ & 424 \\
Judicial and Social Sciences & $36.7 \%(99)$ & $43.9 \%(311)$ & $28.4 \%(83)$ & $31.0 \%(282)$ & 775 \\
Total & 270 & 709 & 292 & 909 & 2180 \\
\hline
\end{tabular}




\subsection{Instrument}

The digital competence of the Higher Education professors was measured with the DigCompEdu Check-In instrument. This questionnaire was adapted to the Spanish context by Cabero-Almenara and Palacios-Rodríguez (2020). The instrument is composed by 6 dimensions and a total of 22 items.

Dimension A, "Professional engagement", is focused on four items related to organizational communication, professional collaboration, reflective practice and digital training. Dimension B, "Digital resources", is composed by three items and is focused on the selection of sources, creation and modification of digital resources, as well as the management of their protection and their sharing. Dimension C, "Teaching and Learning", is composed by four items about how to administer and orchestrate the use of digital tools in teaching and learning. Dimension D, "Assessment" is composed by four items about digital tools and strategies to improve evaluation. Dimension E, "Empowering learners", is composed by four items related with ensuring digital access to the student body, offering learning activities adapted to their level of competence, as well as to their interests and educational needs. Lastly, dimension F, "Facilitating learners 'digital competence", is composed of five items on Media information and literacy, digital communication and collaboration, creation of digital content, responsible use and well-being of technology, and digital solutions of problems. This study lacked sufficient psychometric properties, since the authors had only made expert judgement and analysis of reliability (Cabero-Almenara and Palacios-Rodríguez 2020; Cabero-Almenara et al. 2020); therefore, it will be further verified in this study.

To measure the level of digital competence, a 5-point Likert scale was utilized, scored from zero to four points. For all the items, each value of the scale gradually referred to a level of digital competence, ranging from a basic level (A1 and A2), intermediate level (B1 and B2), to advanced level (C1 and $\mathrm{C} 2$ ), as in the Common European Framework of Reference for Languages (CEFR).

\subsection{Procedure and verification of assumptions}

The analysis of the data includes various procedures. In first place, the lost and atypical cases were filtered from the database. Afterwards, the internal structure of the instrument was verified with the Cronbach's Alpha reliability test and with McDonald's Omega, as well as the validity of the construct through an exploratory factor analysis (EFA), a confirmatory factorial analysis (CFA), convergent validity and discriminant validity. The statistical software SPSS v. 26 and AMOS v.24 were utilized to verify the structural equations modeling (SEM) of the relationships between the items of the instrument.

Lastly, the verification of the ANOVA assumptions: the normality of the data was not met with the Kolmogorov-Smirnov test, neither for the female distribution $(K S=$ $0.062 ; \mathrm{gl}=979 ; p .<0.05)$, nor for the male distribution $(\mathrm{KS}=0.076 ; \mathrm{gl}=1201 ; p .<$ 0.05). However, Srivastava (1959) affirms that the non-normality would not have a serious effect on the distribution of data in large samples. Moreover, Mena et al. (2017) point out that the F statistic from the ANOVA is robust, in terms of Type I errors when the distributions have asymmetry and kurtosis values that vary between -1 and 1 . Table 1 shows the asymmetry and kurtosis for each gender and for each dimension of 
the instrument. Taking into account the results and the sample size of the study $(n=$ 2180 ), the $F$ statistic is robust for the posterior comparisons performed in this study. Also, the homocedasticity assumption of the variances of the groups was verified with Levene's test based on the median, for both distributions: for the female distribution, $F$ $(9,969)=1.831 ; p .>0.05$; and for the male distribution, $F(9,1191)=1.879 ; p .>0.05$.

\section{Analysis of the results}

\subsection{Psychometric properties of the instrument}

To verify the validity of the construct, the sample of participants was divided into two sub-samples extracted randomly (Thompson 2004). The results determined acceptance of the sample with the KMO index (0.961) and Bartlett's sphericity test $\left(\chi^{2}=\right.$ $10,260,603 ; \mathrm{gl}=153 ; p .<0.05)$. It was verified that only 18 items of the 22 were grouped as a function of the theoretical dimension of belonging where they had to remain, with a rotation conversion of 20 iterations. Those items with factorial weights less than 0.3 were eliminated, as recommended by Henson and Roberts (2006). The maximum likelihood Oblimin rotation revealed the presence of six factors, which explained $71.22 \%$ of the variance. The final version of the instrument with the items utilized in this study are shown in Table 2.

Brown and Moore (2014) propose a series of indices along with the values necessary for the model proposed in the CFA to be satisfactory. Mardia's coefficients (M.C.) evidence the multivariate normality, when values between 3 and 70 are found (Byrne 2010); the root mean residual (RMR), with values lower than 0.10 are considered favorable (Meza and Fahoome 2008); a chi-square analysis on the degrees of freedom ( $\chi^{2 / g .1 ;}$ CMIN / DF) with values lower than 5 indicate a good fit (Bentler 1989); the Non-Standard Fit Index (NNFI), the Tucker-Lewis Index (TLI), the comparative fit index (CFI) and the incremental fit index (IFI), considering values higher than 0.90 as a good fit; and the root mean square of approximation (RMSEA) with values between 0.05 and 0.08 (Hu and Bentler 1999); composite reliability (CR) coefficients with values higher than 0.7, the Average Variance Extracted (AVE) with values higher than 0.5 (Hair et al. 2010), and the Maximum Shared Variance (MSV) whose value must be lower than the AVE coefficient (Fornell and Larcker 1981).

For the analysis of reliability, Cronbach's Alpha and McDonald's Omega found very satisfactory levels for the entire instrument, as well as satisfactory in the different dimensions. Table 3 shows the coefficients of each of these adjustments.

\subsection{Comparative analysis of the digital competence in each dimension as related to the field of knowledge of the professors and age range, for each of the genders}

Figure 1 refers to the professional engagement of the professors for using the ICT. It is observed that the level of competence for both female and male teachers is between basic and intermediate, in all areas of knowledge (A2-B1). Specifically, it can be seen that in male teachers, teachers from the area of Social and Legal Sciences are the ones who obtain the highest score. In female teachers, no trend is observed. 
Table 2 Items from the instrument and descriptive variables of asymmetry and kurtosis

\begin{tabular}{|c|c|c|c|c|}
\hline \multirow[t]{2}{*}{ Dimensions } & \multicolumn{2}{|c|}{ Females } & \multicolumn{2}{|l|}{ Males } \\
\hline & $\mathrm{G}_{1}$ & $\mathrm{G}_{2}$ & $\mathrm{G}_{1}$ & $\mathrm{G}_{2}$ \\
\hline A - Professional engagement & 0.04 & -0.22 & 0.09 & -0.43 \\
\hline $\begin{array}{l}\text { - I use the ICT to work with my colleagues within and outside my } \\
\text { organization. }\end{array}$ & 0.12 & -0.29 & 0.01 & -0.10 \\
\hline $\begin{array}{l}\text { - I use different digital channels to improve the communication with } \\
\text { students, family and colleagues. }\end{array}$ & 0.39 & 0.03 & 0.35 & -0.47 \\
\hline - I actively develop my digital competence. & -0.45 & -0.11 & -0.22 & -0.46 \\
\hline B - Digital resources & -0.10 & 0.25 & -0.24 & -0.16 \\
\hline $\begin{array}{l}\text { - I use different websites and search strategies to find and select a broad } \\
\text { selection of digital resources. }\end{array}$ & 0.08 & -0.52 & 0.09 & -0.59 \\
\hline $\begin{array}{l}\text { - I use my own digital resources and modify the existing ones to adapt } \\
\text { them to my needs as an educator. }\end{array}$ & -0.70 & 0.92 & -0.62 & 0.86 \\
\hline - I protect the sensitive content in a safe manner. & -0.28 & -0.37 & -0.35 & -0.60 \\
\hline $\mathrm{C}$ - Teaching and learning & -0.18 & -0.47 & -0.08 & -0.59 \\
\hline $\begin{array}{l}\text { - I supervise the activities and interactions of my students in the online } \\
\text { collaboration environments. }\end{array}$ & -0.42 & -0.37 & -0.21 & -0.71 \\
\hline $\begin{array}{l}\text { - When my students work in groups, they use the ICT to acquire } \\
\text { knowledge. }\end{array}$ & -0.65 & -0.09 & -0.48 & -0.58 \\
\hline $\begin{array}{l}\text { - I use the ICT to allow the students to plan, document and assess their } \\
\text { learning by themselves. }\end{array}$ & -0.05 & -0.42 & -0.06 & -0.55 \\
\hline D - Assessment & 0.59 & 0.23 & 0.695 & -0.02 \\
\hline - I use strategies of digital evaluation to monitor the progress of students. & 0.34 & 0.15 & 0.33 & -0.25 \\
\hline $\begin{array}{l}\text { - I analyze all the available data to identify the students who need } \\
\text { additional support. }\end{array}$ & 0.38 & -0.37 & 0.62 & -0.28 \\
\hline - I use digital technologies to provide effective feedback. & 0.67 & -0.17 & 0.64 & -0.25 \\
\hline E - Empowering learners & 0.10 & -0.86 & 0.372 & -0.78 \\
\hline $\begin{array}{l}\text { - When I propose digital tasks, I consider and address possible problems } \\
\text { such as the equal access to the devices and digital resources. }\end{array}$ & -0.17 & -0.99 & 0.18 & -0.96 \\
\hline - I use the ICT to offer the students personalized learning opportunities. & 0.37 & -0.87 & 0.41 & -0.97 \\
\hline - I use the ICT so that the students actively participate in class. & 0.01 & -0.59 & 0.18 & -0.63 \\
\hline F - Facilitating learners 'digital competence & 0.39 & -0.26 & 0.43 & -0.35 \\
\hline $\begin{array}{l}\text { - I teach the students how to evaluate the reliability of the information they } \\
\text { searched for online and to identify erroneous and/or biased information. }\end{array}$ & 0.18 & -0.73 & 0.40 & -0.62 \\
\hline - I teach the students how to behave safely and responsibly online. & 0.65 & -0.21 & 0.67 & -0.19 \\
\hline - I encourage the students to use the ICT creatively to solve problems. & 0.16 & -0.27 & 0.12 & -0.36 \\
\hline
\end{tabular}

Description: $\mathrm{G}_{1}=$ Asymmetry; $\mathrm{G}_{2}=$ Kurtosis .

For the female teachers, the interaction between the field of knowledge of the professors and the age range was significant, $F(4,969)=6.970, p .<0.05$. More specifically, for female professors aged 40 or under, no significant differences were found. However, for female professors who were 40 years old or older, significant differences were found between the fields: Arts-Humanities and EngineeringArchitecture $(p=0.004)$, Sciences and Engineering-Architecture $(p=0.001)$, and 
Table 3 Construct, discriminant and convergent validity and reliability of the instrument

\begin{tabular}{|c|c|c|c|c|c|c|c|c|c|c|}
\hline$\chi^{2}$ & $\mathrm{gl}$ & Sig. & C.M. & CFI & TLI & IFI & NNFI & RMR & RMSEA & $90 \% \mathrm{CI}$ \\
\hline 4.968 & 118 & 0.001 & 25.495 & 0.955 & 0.942 & 0.955 & 0.944 & 0.0324 & 0.060 & $0.055-0.065$ \\
\hline \multicolumn{4}{|c|}{ Dimensions } & A & $\mathrm{B}$ & $\mathrm{C}$ & $\mathrm{D}$ & $\mathrm{E}$ & $\mathrm{F}$ & TOTAL \\
\hline \multicolumn{4}{|l|}{$\mathrm{CR}$} & 0.740 & 0.711 & 0.819 & 0.827 & 0.789 & 0.777 & \\
\hline \multicolumn{4}{|l|}{ AVE } & 0.589 & 0.521 & 0.601 & 0.616 & 0.555 & 0.539 & \\
\hline \multicolumn{4}{|l|}{ MSV } & 0.873 & 0.873 & 0.819 & 0.819 & 0.785 & 0.785 & \\
\hline \multicolumn{4}{|c|}{ Cronbach's Alpha } & 0.726 & 0.651 & 0.768 & 0.803 & 0.783 & 0.784 & 0.933 \\
\hline \multicolumn{4}{|c|}{ McDonald's Omega } & 0.674 & 0.694 & 0.731 & 0.778 & 0.747 & 0.749 & 0.991 \\
\hline
\end{tabular}

Health Sciences and Engineering-Architecture $(p=0.001)$. For the male professors, significant differences were not found in the professional commitment to use the ICT, with respect to the interaction between the fields of knowledge and age range of the professors, $F(4,1191)=2.062, p .>0.05$.

Figure 2 shows the analysis of the digital resources. Both genres of teaching staff perceived to have a level between basic and intermediate (A2-B1). In the male gender, a trend is observed for both age ranges since it is the area of Engineering and Social Sciences that have higher scores. In the female gender we observe a clear tendency.

For the female professors, the ANOVA model was significant, $F(9,969)=6.400, p$. $<0.05$. Significant differences were found in the interaction between the fields of knowledge of the professors and the age range they belonged to, $F(4,969)=7.130, p$. $<0.05$. For the female professors younger than 40 , differences were found in the use of the ICT between the Sciences and Engineering-Architecture professors $(p .=0.001)$, Health Sciences and Engineering-Architecture $(p=0.001)$ and Judicial-Social Sciences and Engineering-Architecture $(p=0.039)$. For the female professors who were 40 or older, the differences were found between Arts-Humanities and Health Sciences $(p=$ $0.20)$, Arts-Humanities and Engineering-Architecture $(p=0.001)$, Arts-Humanities and Judicial-Social Sciences $(p=0.001)$, Sciences and Engineering-Architecture $(p=$ $0.045)$. For the male professors, the ANOVA model for the interaction between the field of knowledge of the professors and the age range was not significant, $F$ (4, $1191)=1.652, p>0.05$. This indicates that no differences were found in the use of digital resources in each field of knowledge between the professors younger than 40 years old and those 40 or older.
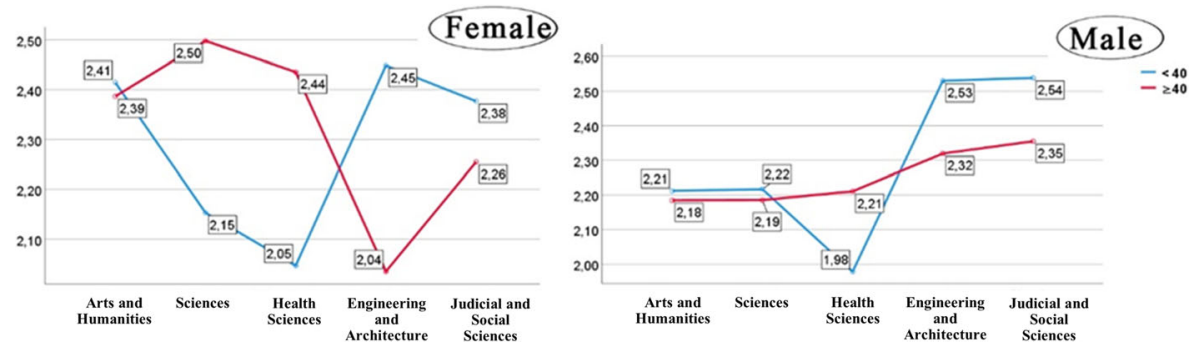

Fig. 1 Professional engagement Dimension 

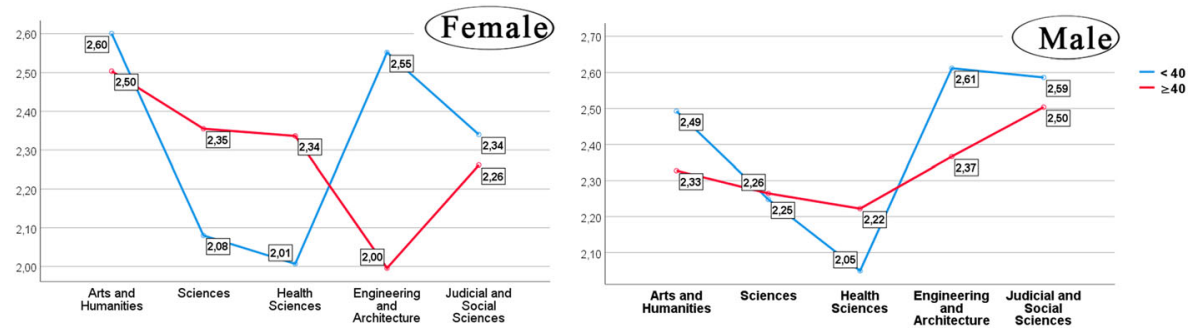

Fig. 2 Digital Resources Dimension

Figure 3 shows the results of the analysis of the pedagogy utilized by the professor to teach students through the use of ICT. Both genres of teaching staff perceived to have a level between basic and intermediate (A2-B1). However, the male gender in the areas of Sciences and Health Sciences has a basic level (A2), for both age ranges. It is also observed that female teachers with more than 40 years in the area of Engineering and Social Sciences (both age ranges), as well as male teachers in the area of Engineering (more than 40 years) and Social Sciences (both ranges of age) are those with a higher score.

For the female professors, the model created with the two factors was significant, $F$ $(9,969)=87.156$, p. $<0.05$. More specifically, the interaction between the field of knowledge and the age range also evidenced significant differences, $F(4,969)=4.366$, $p .<0.05$. For the professors younger than 40, significant differences were found with respect to the pedagogic use between: Sciences and Engineering-Architecture ( $p=$ $0.002)$ and Sciences and Judicial-Social Sciences $(p=0.001)$. For the female professors who were at 40 years of age or older: Arts-Humanities and Engineering-Architecture $(p=0.031)$, Judicial-Social Sciences and Engineering-Architecture $(p=0.001)$ and Sciences and Judicial-Social Sciences $(p=0.023)$. For the male professors, there were no significant differences in the interaction between the variable age ranges and the variable areas of knowledge, $F(4,1191)=0.797, p .>0.05$.

Figure 4 shows the results of the use of digital strategies for the teaching and learning of the students. It is observed that most of the scores are at the basic level (A2), for both genders and both age ranges. We can also see that both genders have higher scores in the area of Engineering (over 40 years) and in the area of Social Sciences (both age ranges).

For the female professors, the model defined with respect to the interaction between the fields of knowledge of the professors within each of the age ranges was significant, $F(4,969)=5.318, p<0.01$. For the female professors younger than 40 , differences
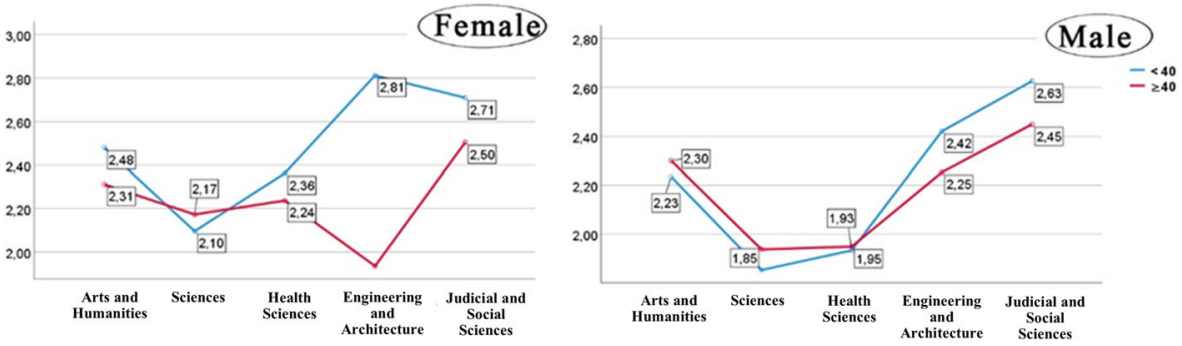

Fig. 3 Teaching and Learning Dimension 

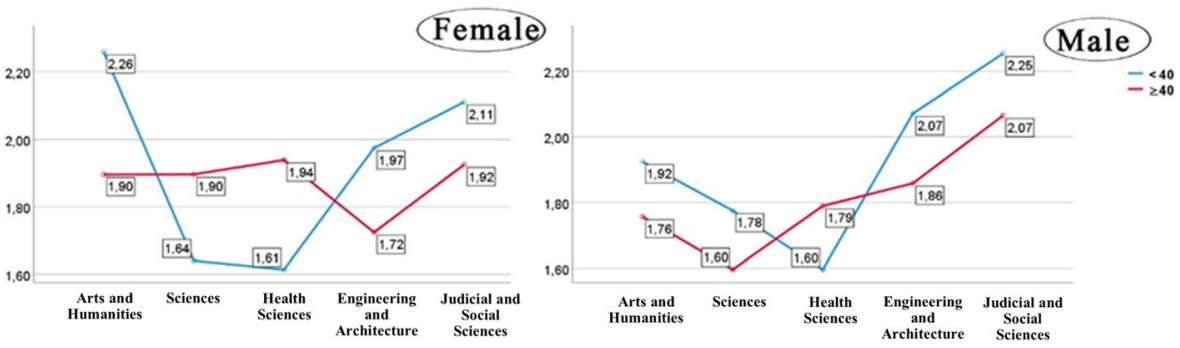

Fig. 4 Assessment Dimension

were found in the use of the ICT resources for evaluation between the fields: ArtsHumanities and Sciences $(p=0.001)$, Arts-Humanities and Health Sciences $(p=$ $0.001)$, Sciences and Judicial-Social Sciences $(p=0.006)$ and Health Sciences and Judicial-Social Sciences $(p=0.003)$. For the female professors who were 40 years old or older, significant differences were not found. For the male professors, the use of the ICT resources for the monitoring and evaluation of the students was not significant for the interaction between the field of knowledge of the professors and the age range, $F(4,1192)=1.550, p .>0.05$. This indicates that no significant differences were found in the use of ICT resources for evaluation, for those younger than 40 years old, or those who were 40 or older.

Figure 5 alludes to providing equal access to the students on the use of ICT resources, and personalizing the teaching according to the specific ICT required by the students. It is observed that in female teachers, most of the scores are between basic and intermediate level (A2-B1), but in male teachers they are in basic level (A2). In the female gender there is no trend regarding the age ranges and area of knowledge, but in the male teaching staff there is a trend, where the Engineering and Social Sciences teaching staff have higher scores.

For the female professors, significant differences were found between the fields of knowledge and each age range, $F(4,969)=2.610$, p. $<0.05$. For the professors younger than 40, significant differences were found in the fields: Arts-Humanities and Sciences $(p=0.001)$, Sciences and Judicial-Social Sciences $(p=0.001)$. For the professors aged 40 or older: Arts-Humanities and Sciences $(p=0.001)$, ArtsHumanities and Engineering-Architecture $(p=0.001)$, Sciences and Judicial-Social Sciences $(p=0.032)$, Health Sciences and Engineering-Architecture $(p=0.002)$ and Judicial-Social Sciences and Engineering-Architecture $(p=0.001)$. For the male professors, no significant differences were found when comparing the fields of knowledge
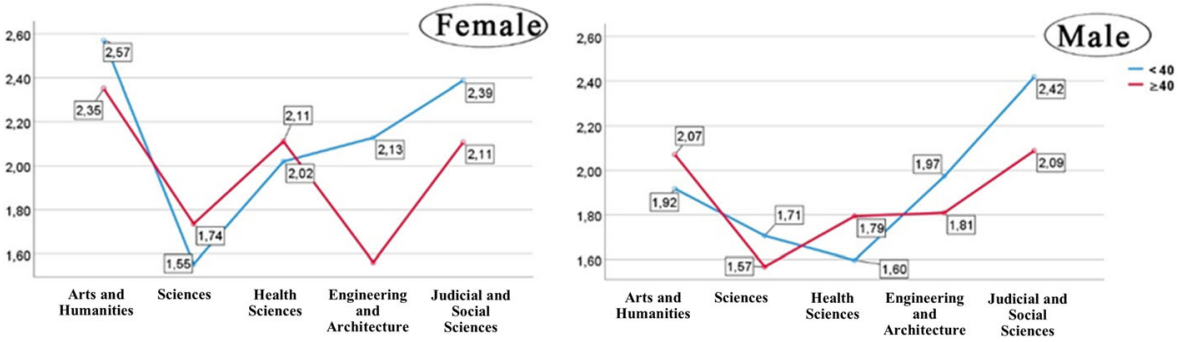

Fig. 5 Empowering learners dimension 
in each age range with equal access of the ICT resources for tending to the needs of the students, $F(4,1191)=2.125, p .>0.05$. That is to say, there were no differences on the use of the ICT resources neither for professors younger than 40, nor those who were 40 or older.

Figure 6 refers to the question if the professors promote and develop the digital competence of the students so that they acquire this competence in a creative, critical and safe manner. It is observed that most of the scores for both genders are at the basic level (A1-A2). For male teachers, the trend in the areas of Engineering and Social Sciences is clearer with respect to female teachers, for both age ranges.

The ANOVA with the fields of knowledge as a function of the age range was not significant for the male professors, $F(4,1191)=1.383, p .>0.05$; although differences were found for female professors as a function of age, $F(4,969)=2.524, p .<0.05$. More specifically, for those younger than 40, significant differences were found between Sciences and Judicial-Social Sciences $(p=0.001)$, and for those older than 40, between the fields: Arts-Humanities and Sciences $(p=0.001)$, Arts-Humanities and Health Sciences $(p=0.001)$, Arts-Humanities and Engineering-Architecture $(p=$ $0.001)$, Sciences and Judicial-Social Sciences $(p=0.021)$ and Judicial-Social Sciences and Engineering-Architecture $(p=0.001)$.

Lastly, Fig. 7 refers to the level of total digital competence of the Higher Education professors from the five fields of knowledge where they belong to, classified according to gender. It is observed that in female teachers there is no clear trend, for both age ranges. However, for male teachers, the trend for Engineering and Social Sciences areas is much clearer, obtaining higher scores for both age ranges. In addition, the level of global digital competence is associated with a level between basic and intermediate (A2-B1).

For female professors, significant differences were found between the five fields of knowledge as a function of age, $F(4,969)=5.257, p .<0.05$. More specifically, for the female younger than 40 , differences were found in digital competence in the fields: Arts-Humanities and Sciences $(p=0.001)$, ArtsHumanities and Health Sciences $(p=0.021)$, Sciences and Judicial-Social Sciences $(p=0.001)$, Health Sciences and Judicial-Social Sciences $(p=0.007)$. On the other hand, for those 40 or older, significant differences were found between: Arts-Humanities and Engineering-Architecture $(p=0.001)$, Health Sciences and Engineering-Architecture $(p=0.001)$ and Judicial-Social Sciences and Engineering-Architecture $(p=0.001)$.
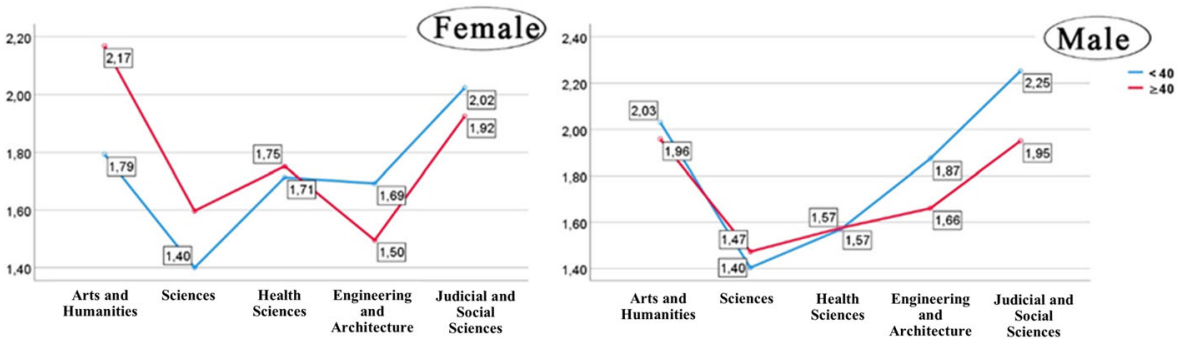

Fig. 6 Facilitating learners 'digital competence dimension 

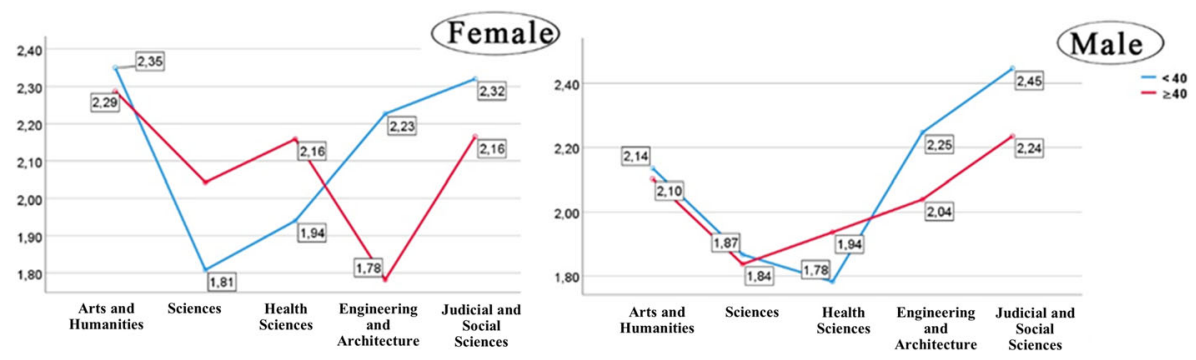

Fig. 7 Total Digital Competence

However, for the male professors, significant differences in their digital competence were not found when comparing their fields of knowledge they belonged to and each age range studied, $\mathrm{F}(4,1191)=1.752, \mathrm{p} .>0.05$.

\section{Discussion}

This study had two purposes: on the one hand, to know descriptively the level of digital competence of teachers in each area of knowledge, for each gender and age ranges; and, on the other hand, statistically comparing whether there are significant differences in scores between teachers in the different areas of knowledge, for each gender.

Regarding the first purpose, the results highlight the lack of digital training of teachers, both for both genders, both age ranges, and different areas of knowledge. All of them obtained scores associated between basic and intermediate level (A2-B1). These results are similar to those found by Dzikite et al. (2017) and Ojeniyi and Adetimirin (2016) which stated that teachers used to have low digital competence, not in accordance with the objectives to be achieved set by the emerging technologies of the Horizon reports (Alexander et al. 2019) whose digital teacher competence is the key to training future graduates for the professions of the twenty-first century (Olszewski and y Crompton 2020).

In relation to the areas of knowledge, it has been observed that in the male teaching staff there is a certain trend with the areas of Engineering-Architecture and Social-Legal Sciences, since both areas had higher scores than the other areas. These results are partially corroborated by Eloy et al. (2019) who found adequate digital training, however, not from the pedagogical point of view (Rodriguez and Martinez 2015). For example, for male teachers in the Health Sciences area, the global level in digital skills is associated with the basic level (A1-A2), corroborating the results of Humanante-Ramos et al. (2019) and Kingsley and Kingsley (2009) who found a lack in the lack of digital training related to the management, generation and dissemination of information, although it is true that teachers in this area usually show a special interest in learning (Fernández, 2019).

Regarding the age ranges, it has been descriptively observed that in the areas of Engineering-Architecture and Social-Legal Sciences, teachers over 40 years of age have higher scores in the level of digital competence compared to teachers who are 40 years or less. These results are contradictory to those stated by Fernández-Cruz and Fernández-Díaz (2016), Gallardo et al. (2018) and Garzón et al. (2020) who stated that 
older teachers had lower ICT training than those who are younger. For example, in the dimension use of digital resources (B), male teachers over 40 have higher scores than those under 40 , so there is a positive correlation with age ranges in management technical and instrumental of these digital resources by teachers, statements contradictory to those of Fernádez dela et al. (2016) and López et al. (2019) who also stated that younger teachers had a higher level of instrumental skills. Perhaps a possible explanation for why these areas have a higher competence profile is due to the type of knowledge they teach. For example, engineering teachers are in constant use with technologies, however, as pointed out by Rodriguez and Martinez (2015), they do not use them from a didactic point of view. These findings are important so that when training courses for teachers are carried out, each area of knowledge has the appropriate course for its pedagogical or instrumental deficiencies, allowing for a correct use of the technology in the different teaching-learning scenarios (Cabero-Almenara and Barroso 2016; Pozos and Tejada 2018; Mercader 2019, 2020; Pérez-Díaz 2019; Guillén-Gámez and Mayorga-Fernández, 2020b; Padilla-Hernández et al. 2020).

The second purpose of this research was related to the discovery and comparison of the digital competence of the Higher Education professors in Andalusia in the different fields of knowledge to which they belonged to, classified into two age ranges (younger than 40 and older than 40), for each gender. It was verified how, in a general manner, the female professors showed significant differences as a function of age and fields of knowledge, while the same results were not found for male professors. Along this line, the results are similar to those from Siddiq and Scherer (2019) and Cai et al. (2017), in which the gender differences were more positive and significant for the female gender. In spite of this, their findings, contrasted with previous meta-analyses which were based on ICT literacy, suggested that the gender digital divide could not have been as severe as suggested. Altogether, the results showed significant differences with respect to the interaction between the competence dimension, field of knowledge and age range. As can be observed in the figures presented (1-6), the scores provided by the educators older than 40 were, in general, lower than the rest of their colleagues. These same results are contradictory in previous studies, where it was shown that one of the variables that had an effect on the DCE was age, with a negative correlation (GallardoEchenique et al. 2018; Garzón et al. 2020). These results suggest that the training courses must also be focused and adapted not only to female teachers, which is where the greatest differences have been found, but also to each age range, requiring basic, intermediate and specialized courses of the use of ICT.

\section{Conclusions}

Training in digital competence of Higher Education teachers is a key piece to be able to have a quality education, and more so in the difficult times that we are currently going through due to Covid-19. If ICT had not been integrated into the teaching-learning process during this last year, possibly the teaching by the teachers would not have been able to perform.

The findings of this study highlight the lack of digital training for both genders of teachers, finding greater differences between areas of knowledge for female teachers and for teachers with the same or less than 40 years. Having a basic-intermediate level is no longer enough in this complex year, but requires a specialized teacher within their 
area of knowledge, in those technologies that can provide better training to their students, always from a point of view didactic. Therefore, Spanish university institutions that wish to improve the digital training of their teaching staff, must organize training courses, taking into account the results analyzed for these variables. Perhaps a possible solution to attract teachers to these courses is to encourage them with reduced hours, better salaries, or even with prestige through official merits.

One of the limitations of the present study is that the type of design utilized (crosssectional) makes impossible the comparison of the digital competence of the professors between both age ranges, as they are independent groups. As a future research study, it would be necessary to utilize a longitudinal design in order to be able to study the effect of age changes, and thus, to justify the maturation of the growing rate of digital competence of the Higher Education professors.

Another of the limitations of the study is the use of the non-probabilistic sampling utilized, which makes difficult the generalization of the data. As a future work, the possibility of selecting the Higher Education professors through a random cluster sampling method, between those who work in public or private universities will be studied, as the specialized literature indicates that the access to ICT resources and infrastructure of the centers could affect their development.

Finally, a third limitation is that this is a self-reported survey, so participants may have answered with what they think they are doing as opposed to their actual practice. Also, it would be interesting to determine why engineering shows such huge differences between the two age groups across most dimensions.

Availability of data and materials This study does not offer data collection.

Code availability Not applicable.

Authors' contributions FG designed our research and structure of the paper. JC, JR, and AP validated this analysis. FG wrote the original draft and JC, JR, and AP reviewed the draft, and edited this article. FG conducted data curation and visualization. All authors equally contributed to write and review this article. Finally, all authors read and approved the final manuscript.

Funding "Design, production and evaluation of the t-MOOC for the acquisition of digital competences of University professor" (Ref. US-1260616). Project financed by the Junta of Andalusia (Economics, Knowledge, Business and University Council and the European Regional Development Funds).

\section{Declarations}

Conflicts of interest/competing interests The authors declare that they have no competing interests.

\section{References}

Alexander, B., Ashford-Rowe, K., Barajas-Murph, N., Dobbin, G., Knott, J., McCormack, M., \& Weber, N. (2019). Horizon report 2019 higher education edition. EDUCAUSE.

Amhag, L., Hellström, L., \& Stigmar, M. (2019). Teacher Educators' use of digital tools and needs for digital competence in higher education. Journal of Digital Learning in Teacher Education, 35(4), 203-220. https://doi.org/10.1080/21532974.2019.1646169. 
Andres, P., \& Svoboda, P. (2018). Development of digital competences of teachers of social sciences at secondary vocational schools. In International Conference on Interactive Collaborative Learning ( $p p$. 720-731). Cham: Springer. https://doi.org/10.1007/978-3-030-11935-5_68.

Baek, S. G., Lim, C. I., Kim, H. S., Yu, Y. L., Kim, M. R., Lee, S. R. (2010). Analysis of influential variables on performance-based ICT literacy level for korean students. In E-Learn: World Conference on ELearning in Corporate, Government, Healthcare, and Higher Education (pp. 1560-1565). Association for the Advancement of computing in education.

Baloğlu, M., \& Çevik, V. (2008). Multivariate effects of gender, ownership, and the frequency of use on computer anxiety among high school students. Computers in Human Behavior, 24(6), 2639-2648. https:// doi.org/10.1016/j.chb.2008.03.003.

Bentler, P. M. (1989). EQS structural equations program manual. Los Angeles: BMDP Statistical Software.

Brown, T. A., Moore, M. T. (2014). Conformatory factor analysis. En R. H. Hoyle (Ed.), Handbook of structural equation modeling (pp. 361-379). New York: Guilford.

Burgos, D. (2019). Read, watch, do: Developing digital competence for university educators. Springer nature. https://doi.org/10.1007/978-3-030-31284-8 7.

Butcher, N. (2019). Marco de competencias docentes en materia de TIC UNESCO. París: UNESCO.

Byrne, B. M. (2010). Structural equation modeling with AMOS: Basic concepts, applications, and programming (multivariate applications series) (Vol. 396, p. 7384). New York: Taylor \& Francis Group.

Cabero Almenara, J., \& Martínez Gimeno, A. (2019). Las tecnologías de la información y comunicación y la formación inicial de los docentes: modelos y competencias digitales. Profesorado: Revista de Currículum y Formación de Profesorado, 23(3), 247-268.

Cabero Almenara, J., Roig Vila, R., \& Mengual Andrés, S. (2017). Technological, pedagogical, and content knowledge of future teachers according to the TPACK model. Digital Education Review, 32, 85-96.

Cabero-Almenara, J., Barroso-Osuna, J., Palacios-Rodríguez, A., \& Llorente-Cejudo, C. (2020). Marcos de Competencias Digitales para docentes universitarios: su evaluación a través del coeficiente competencia experta. Revista Electrónica Interuniversitaria De Formación Del Profesorado, 23(2). https://doi.org/10. 6018/reifop.413601.

Cabero-Almenara, J., y Barroso, J. (2016). ICT teacher training: A view of the TPACK model. Cultura y Educación, 28(3), 633-663. https://doi.org/10.1080/11356405.2016.1203526.

Cabero-Almenara, J., Barroso-Osuna, J., Palacios-Rodríguez, A., \& Llorente-Cejudo, C. (2020). Marcos de Competencias Digitales para docentes universitarios:su evaluación a través del coeficiente competencia experta. Revista Electrónica Interuniversitaria De Formación Del Profesorado, 23(2). https://doi.org/10. 6018/reifop.413601.

Cai, Z., Fan, X., \& Du, J. (2017). Gender and attitudes toward technology use: A meta-analysis. Computers \& Education, 105, 1-13. https://doi.org/10.1016/j.compedu.2016.11.003.

Cooper, J., \& Weaver, K. D. (2003). Gender and computers: Understanding the digital divide. Psychology Press.

Crompton, H. (2017). ISTE Standars for educators: A guide for teachers and other professionals. Arlington: International Society for Technology in Education.

Deumal, G., \& Guitert, M. (2015). La competencia digital en la enseñanza del diseño. El caso de BAU Centro Universitario de Diseño de Barcelona (UVic). RELATEC: Revista Latinoamericana de Tecnología Educativa, 14(2), 51-65. https://doi.org/10.17398/1695-288X.14.2.51.

Durán Cuartero, M., Gutiérrez Porlán, I., \& Prendes Espinosa, M. P. (2016). Certificación de la competencia TIC del profesorado universitario: Diseño y validación de un instrumento. Revista mexicana de investigación educativa, 21(69), 527-556 Recuperado el 24 de mayo de 2020, de http://www.scielo.org.mx/scielo.php?script=sci_arttext\&pid=S1405-66662016000200527\&lng= es\&tlng=es.

Dzikite, C., Nsubuga, Y., \& Nkonki, V. (2017). Lecturers' competencies in information and communication technology (ICT) for effective implementation of ICT-integrated teaching and learning in textiles and clothing degree Programmes. International Journal of Educational Sciences, 17(1-3), 61-68. https://doi. org/10.1080/09751122.2017.1305756.

Education and Training Foundation. (2019). Digital teaching professional framework. Taking Learning to the Next Level. London: JISC.

Elliot, J., Gorichon, S., Irigoin, M., \& Maurizi, M. (2011). Competencias y Estándares TIC para la Profesión Docente. Santiago: Ministerio de Educación. 
Eloy, S., Dias, M. S., Lopes, P. F., \& Vilar, E. (2019). Digital Technologies in Architecture and Engineering: Exploring an engaged interaction within curricula. In Architecture and Design: Breakthroughs in Research and Practice (pp. 390-426). IGI global. https://doi.org/10.4018/978-1-5225-7314-2.ch014.

European Union Council. (2018). Council Recommendation of 22 May 2018 on key competences for lifelong learning. Official Journal of the European Union.

Fernanda, M., Saavedra, C., De, M., Nacional, E., Del Pilar, P., Barrios, M., \& Zea, C. (2013). Competencias tic para el desarrollo profesional docente. Bogotá: Ministerio de Educación Nacional.

Fernádez dela Iglesia, J. C., Fernández Morante, M. C., \& Cebreiro López, B. (2016). Competencias en TIC del profesorado en Galicia: variables que inciden en las necesidades formativas. Innovación Educativa, 26. https://doi.org/10.15304/ie.26.3256.

Fernández Luque, A. M. (2019). On-the-job digital competence training for health professionals. Revista Cubana de Información en Ciencias de la Salud (ACIMED), 30(2), 1-21.

Fernández-Cruz, F.-J., \& Fernández-Díaz, M.-J. (2016). Los docentes de la generación Z y sus competencias digitales - Generation Z's teachers and their digital skills. Revista Comunicar, 24(46), 97-105. https://doi. org/10.3916/C46-2016-10.

Fernández-Luque, A. M., Cordón-García, J. A., \& Gómez-Díaz, R. (2017). Digital competences in the curriculum of postgraduate studies of health professionals: The role of the librarian as trainer in formative programmes. In Proceedings of the 5th International Conference on Technological Ecosystems for Enhancing Multiculturality (pp. 1-6). ACM.

Fernández-Márquez, E., Leiva-Olivencia, J. J., \& López-Meneses, E. (2017). Competencias digitales en docentes de Educación Superior. Revista Digital de Investigación en Docencia Universitaria, 12(1), 213-231. https://doi.org/10.19083/ridu.12.558.

Fornell, C., \& Larcker, D. F. (1981). Evaluating structural equation models with unobservable variables and measurement error. Journal of Marketing Research, 18(1), 39-50.

Gallardo-Echenique, E., Poma, A., \& Esteve, F. (2018). La competencia digital: análisis de una experiencia en el contexto universitario. Academicus, 12(1), 6-15.

Garzón, E., Sola, T., Ortega, J., Marín, J., \& Gómez, G. (2020). Teacher training in lifelong learning. The Importance of Digital Competence in the Encouragement of Teaching Innovation. Sustainability, 12, 2852. https://doi.org/10.3390/su12072852.

Ghomi, M., \& Redecker, C. (2019). Digital competence of educators (DigCompEdu): Development and evaluation of a self-assessment instrument for teachers' digital competence. In Proceedings of the 11th international conference on computer supported education (pp. 541-548). SCITEPRESS. https://doi.org/ $10.5220 / 0007679005410548$.

Guillén-Gámez, F., \& Mayorga-Fernández, M. (2020a). Quantitative-comparative research on digital competence in students, graduates and professors of faculty education: An analysis with ANOVA. Education and Information Technologies, 25, 4157-4174. https://doi.org/10.1007/s10639-020-10160-0.

Guillén-Gámez, F., Mayorga-Fernández, M. (2020b). Quantitative-comparative research on digital competence in students, graduates and professors of faculty education: An analysis with ANOVA. Educ Inf Technol, 1-18. https://doi.org/10.1007/s10639-020-10160-0.

Guillén-Gámez, D., Ruiz-Palmero, J., Sánchez-Rivas, E., \& Colomo-Magaña, E. (2020). ICT resources for research: An ANOVA análisis on the digital research skills of higher education teachers comparing the areas of knowledge within each gender. Education and Information Technologies, 25, 4575-4589. https:// doi.org/10.1007/s10639-020-10176-6.

Guri-Rosenblit, S. (2018). E-teaching in higher education: An essential prerequisite for e-learning. Journal of New Approaches in Educational Research, 7(2), 93-97. https://doi.org/10.7821/naer.2018.7.298.

Hair, J., Black, W., Babin, B., \& Anderson, R. (2010). Multivariate data analysis. USA: Prentice-Hall.

Henson, R. K., \& Roberts, J. K. (2006). Use of exploratory factor analysis in published research: Common errors and some comment on improved practice. Educational and Psychological Measurement, 66(3), 393-416. https://doi.org/10.1177/0013164405282485.

Hu, L., \& Bentler, P. M. (1999). Cutoff criteria for fit indexes in covariance structure 17 analysis: Conventional criteria versus new alternatives. Structural Equation 18 Modeling: A Multidisciplinary Journal, 6(1), 1-55.

Humanante-Ramos, P., Solís-Mazón, M. E., Fernández-Acevedo, J., \& Silva-Castillo, J. (2019). Las competencias TIC de los estudiantes que ingresan en la universidad: una experiencia en la Facultad de Ciencias de la Salud de una universidad latinoamericana. Educación Médica, 20(3), 134-139. https://doi. org/10.1016/j.edumed.2018.02.002.

INTEF (2017). Marco Común de Competencia Digital Docente. Ministerio de Educación. 
Jackson, L. A., Zhao, Y., Kolenic III, A., Fitzgerald, H. E., Harold, R., \& Von Eye, A. (2008). Race, gender, and information technology use: The new digital divide. Cyberpsychology \& Behavior, 11(4), 437-442. https://oi.org/10.1089/cpb.2007.0157.

Kingsley, K. V., \& Kingsley, K. (2009). A case study for teaching information literacy skills. BMC Medical Education, 9(1), 1-6. https://doi.org/10.1186/1472-6920-9-7.

Krumsvik, R. J., Jones, L. Ø., Øfstegaard, M., \& Eikeland, O. J. (2016). Upper secondary school teachers' digital competence: Analysed by demographic, personal and professional characteristics. Nordic Journal of Digital Literacy, 11(03), 143-164.

Lázaro-Cantabrana, J., Usart-Rodríguez, M., \& Gisbert-Cervera, M. (2019). Assessing teacher digital competence: The construction of an instrument for measuring the knowledge of preservice teachers. Journal of New Approaches in Educational Research, 8(1), 73-78. https://doi. org/10.7821/naer.2019.1.370.

López, J., Pozo, S., Fuentes, C. y Romero, J.M. (2019). Análisis del Liderazgo Electrónico y la Competencia Digital del Profesorado de Cooperativas Educativas de Andalucía (España). Multidisciplinary Journal of Educational Research, 9(2), 194-223. https:/doi.org/10.4471/ remie.2019.4149.

López-Pena, V., López-Chao, V., \& Ramiro-Aparicio, D. (2017). A study of the IT competence training in technical drawing in higher education. In Proceedings of the 5th International Conference on Technological Ecosystems for Enhancing Multiculturality (pp. 1-5).

Mena, B., José, M., Alarcón, R., Arnau Gras, J., Bono Cabré, R., \& Bendayan, R. (2017). Non-normal data: Is ANOVA still a valid option?. Psicothema, vol. 29, num. 4, p. 552-557

Mercader, C. (2019). Las resistencias del profesorado universitario a la utilización de las tecnologías digitales. Aula Abierta, 48(2), 167-174. https://doi.org/10.17811/rifie.48.2.2019.167-174.

Mercader, C. (2020). Explanatory model of barriers to integration of digital technologies in higher education institutions. Education and Information Technologies, 25, 5133-5147. https://doi.org/10.1007/s10639020-10222-3.

Meza, J. P., \& Fahoome, G. F. (2008). The development of an instrument for measuring healing. The Annals of Family Medicine, 6(4), 355-360.

Mirete, A. B. (2016). El profesorado universitario y las TIC. Análisis de su competencia digital. Ensayos, Revista de la Facultad de Educación de Albacete, 31(1), 133-147.

Ojeniyi, A. O., \& Adetimirin, A. E. (2016). ICT literacy skills and electronic information resources use by lecturers in two private universities in Oyo state, Nigeria. Library Philosophy and Practice, 1-19.

Olszewski, B., y Crompton, H. (2020). Educational technology conditions to support the development of digital age skills. Computers and Education, 150. https://doi.org/10.1016/j.compedu. 2020.103849

Padilla-Hernández, A., Gámiz-Sánchez, V., y Romero-López, M. (2020). Evolution of higher education teachers' digital competence: Critical incidents derived from life stories. Educar, 56(1), 109-127. https://doi.org/10.5565/rev/educar.1088.

Pérez-Díaz, R. (2019). Teaching digital competence in the teacher training institutes: Case of the Dominican Republic. Pixel-Bit. Revista de Medios y Educación, 55, 75-97. https://doi.org/10.12795/pixelbit.2019. i55.05.

Pozos, K., y Tejada, J. (2018). Digital competences teachers in higher education: Mastery levels and training needs. Digital Research in University Teaching, 12(2), 59-87. https://doi.org/10. 19083/ridu.2018.712.

Redecker, C., \& Punie, Y. (2017). Digital competence of educators DigCompEdu. Publications Office of the European Union. https://doi.org/10.2760/159770.

Rodriguez, F. M., \& Martinez, J. G. (2015). Use and appropriation of information and communication technologies by teachers in the faculties of engineering/Uso y apropiacion de las Tecnologias de la Informacion y la Comunicacion por parte de los docentes en las facultades de ingenieria. Redes de Ingenieria, 6(1), 6-25.

Rodríguez-García, A. M., Trujillo-Torres, J. M., \& Sánchez-Rodríguez, J. (2019a). Impacto de la productividad científica sobre competencia digital de los futuros docentes: aproximación bibliométrica en Scopus y Web of Science. Revista Complutense De Educación, 30(2), 623-646. https://doi.org/10. 5209/RCED.58862.

Rodríguez-García, A., Raso, F., y Ruiz-Palmero, J. (2019b). Competencia digital, educación superior y formación del profesorado: un estudio de meta-análisis en la web of science. Pixel-Bit, 54(4), 65-81. https://doi.org/10.12795/pixelbit.2019.i54.04 
Siddiq, F., \& Scherer, R. (2019). Is there a gender gap? A meta-analysis of the gender differences in students' ICT literacy. Educational Research Review, 27, 205-217.

Silva, J., Lázaro, J.L., Miranda, P., Morales, M. J., Gisbert, M., Rivoir, A., Onetto, A. (2019). La Competencia Digital Docente en Formación Inicial: Estudio a Partir de los Casos de Chile y Uruguay. Education Policy Analysis Archives, 27.

Srivastava, A. B. L. (1959). Effect of non-normality on the power of the analysis of variance test. Biometrika, 46(1/2), 114-122.

Tena, R. R., Almenara, J. C., \& Osuna, J. B. (2016). E-learning of Andalusian University's lecturers. Gender. Turkish Online Journal of Educational Technology-TOJET, 15(2), 25-37.

Thompson, B. (2004). Exploratory and confirmatory factor analysis: Understanding concepts and applications. Washington: American Psychological Association.

Publisher's note Springer Nature remains neutral with regard to jurisdictional claims in published maps and institutional affiliations.

\title{
Affiliations
}

\section{Julio Cabero-Almenara ${ }^{1}$ • Francisco D. Guillén-Gámez ${ }^{2}$ • Julio Ruiz-Palmero ${ }^{3}$. Antonio Palacios-Rodríguez ${ }^{1}$}

\author{
Julio Cabero-Almenara \\ cabero@us.es \\ Francisco D. Guillén-Gámez \\ dguillen@uco.es \\ Julio Ruiz-Palmero \\ julioruiz@uma.es
}

1 University of Seville, Sevilla, Spain

2 University of Cordoba, Córdoba, Spain

3 University of Malaga, Málaga, Spain 